\section{USDA, ARS EOM 402-10 High $\beta$-Carotene Cucumber}

Jack E. Staub ${ }^{1,2}$ and Philipp W. Simon

Vegetable Crops Research, U.S. Department of Agriculture, Agricultural Research Service, Department of Horticulture, University of Wisconsin, Madison, WI 53706

\section{Hugo E. Cuevas}

U.S. Department of Agriculture, Agricultural Research Service, Tropical Agricultural Research Station, 2200 P.A. Campos Avenue, Mayaguez, PR 00680-5470

Additional index words. Cucumis sativus, vitamin A, human nutrition

The Agricultural Research Service, U.S. Department of Agriculture, released the high $\beta$-carotene cucumber (Cucumis sativus var. sativus L.) line EOM 402-10 in Jan. 2011. Line EOM 402-10 was made available to U.S. cucumber breeders to supply a source from which they may develop elite germplasm possessing high levels of $\beta$-carotene as a natural source of vitamin A to the human diet (i.e., improve nutritional value of cucumber). This germplasm is fixed for genes controlling the expression of $\beta$-carotene in mature (2 to $5 \mathrm{~cm}$ in diameter) greenhousegrown fruit (Cuevas et al., 2010). Therefore, line EOM 402-10 can be used directly in breeding programs for the introgression of three $\beta$-carotene genes (Cuevas et al., 2010; Navazio and Simon, 2001) into elite germplasm. Moreover, the relatively short life cycle of cucumber (3 to 4 months) makes EOM 402-10 an attractive candidate for use in functional genomics studies that seek to clarify carotenoid accumulation in higher plants.

\section{Origin}

The XIS (Cucumis sativus var. xishuangbannanesis Qi et Yuan; $2 \mathrm{n}=2 \mathrm{x}=14$ ) is cultivated in southern Yunnan province, P.R. China. This exotic germplasm was introduced into the United States in 1987, produces fruit that possess an orange-colored endocarp/mesocarp (as a result of the presence of $\beta$-carotene), and is cross-compatible with cultivated cucumber (Simon and Navazio, 1997). Previously, crosses were made between

Received for publication 18 Jan. 2011. Accepted for publication 25 Mar. 2011.

Mention of a trade name, proprietary product, or specific equipment does not constitute a guarantee or warranty by the USDA and does not imply its approval to the exclusion of other products that may be suitable.

${ }^{1}$ Currently at the U.S. Department of Agriculture, Agricultural Research Service, Forage and Range Research Laboratory, Utah State University, 696 E. 1100 N., Logan, UT 84322-6300.

${ }^{2}$ To whom reprint requests should be addressed; e-mail jack.staub@ars.usda.gov.
XIS (PI 509549) and 10 U.S. pickling cucumber cultigens (i.e., cultivars, breeding lines, and accessions) to produce progeny segregating for yellow and orange internal fruit (mesocarp/endocarp) color. Recurrent selection for internal orange fruit color in 'SMR 18 ' and 'Addis' (C. sativus L. var. sativus; $2 n=2 x=14$, white-green flesh color) by XIS matings resulted in three segregating "high $\beta$-carotene" cucumber populations [Early Orange Mass 400 (EOM 400), Early Orange Mass 402 (EOM 402), and Late Orange Mass 404 (LOM 404)] (Simon and Navazio, 1997). These populations also segregated for fruit shape, size, and exterior and interior quality.

Initially, seeds from EOM 402, LOM 404, and $\mathrm{EOM} 400$ were germinated, and $\approx 100$ sativus $\mathrm{L}$.). plants were transplanted at the three-leaf stage to enclosed cages (3) in 2003, where bees were introduced to increase seed of each population. Subsequently, mature fruit of 50 plants from each of these populations were evaluated visually in the field at Hancock, WI, in the summer of 2004 for the expression of orange flesh color (i.e., $\beta$-carotene accumulation). Eleven plants from the EOM 402 population were selected, and meristem cuttings were taken and grown to maturity in a greenhouse (Madison, WI). Plants obtained from these meristem cuttings were self-pollinated and intercrossed, and mature greenhouse-grown fruits were evaluated visually for relative degree of mesocarp and endocarp pigmentation. Individual plants bearing fruits with orange interiors and possessing U.S. pickling market traits were selected. Fruits derived from self-pollinations were visibly more orange than those derived from sib-pollinations. Therefore, selection for orange pigmentation and inbreeding was conducted using self-pollinated fruit in a greenhouse for four generations to produce an $\mathrm{S}_{4}$ line (a selection from EOM 402) designated 'EOM 402-10' (in 2007) that produced truebreeding orange-pigmented fruit (i.e., orange flesh color; Fig. 1).

\section{Description}

Line EOM 402-10 is the result of selection in the EOM 402 population that was derived from crossing a U.S. pickling market type [moderately warty, no endocarp/mesocarp pigment, fruit length:diameter $(\mathrm{L}: \mathrm{D})=$ 2.8:1.0 to $3.4: 1$ ] with Chinese type XIS

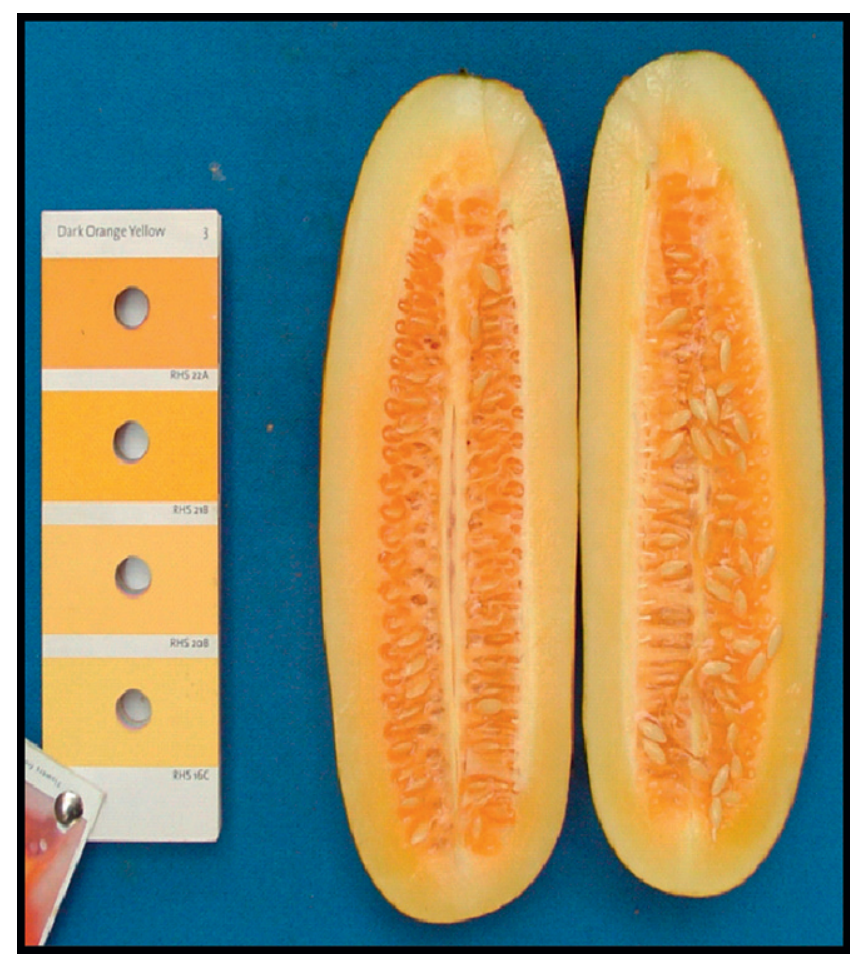

Fig. 1. Greenhouse-grown fruit (2007) of USDA-ARS EOM 402-10 high $\beta$-carotene cucumber (Cucumis 
(extremely warty, orange pigment, fruit L:D = 1.5:1 to 3:1) (Simon and Navazio, 1997). EOM 402-10 (fruit L:D = 2.8:1 to 3.8:1) was selected for orange internal fruit pigmentation and U.S. pickling market characteristics (Fig. 1). This line is uniform for fruit shape, size, and exterior quality, and orange color is observed in exocarp and mesocarp tissue. Although orange internal fruit pigmentation was mainly observed in mature fruit (USDA grade sizes $3 b$ and $4 a$ ) (Cuevas et al., 2010), preliminary inspection of immature fruit (grade size 1a-2b) indicated that orange color hue varies depending on greenhouse-growing conditions (unpublished data).

The mean and SE of mesocarp $\beta$-carotene content of mature EOM 402-10 greenhousegrown fruit is $2.72 \mu \mathrm{g} \cdot \mathrm{g}^{-1} \pm 1.15$ of fresh tissue, which is significantly higher than mesocarp of U.S. pickling cucumber $(0.02$ $\mu \mathrm{g} \cdot \mathrm{g}^{-1} \pm 0.00$; Cuevas et al., 2010). Likewise, the endocarp $\beta$-carotene content of EOM $402-10$ of fresh tissue $\left(7.54 \mu \mathrm{g} \cdot \mathrm{g}^{-1} \pm 0.68\right)$ is higher than U.S. pickling cucumber $(0.16$ $\mu \mathrm{g} \cdot \mathrm{g}^{-1} \pm 0.08$ of fresh tissue). The $\beta$-carotene content (meoscarp and endocarp) of EOM 402-10 is similar to that of the original germplasm EOM 402 from which it was derived. An inheritance study using EOM 402-10 germplasm determined that two recessive genes control the $\beta$-carotene content (i.e., orange flesh) in the mesocarp, whereas one recessive gene controls $\beta$-carotene content in endocarp tissue (Cuevas et al., 2010). This simple inheritance provides an opportunity for the introgression of those genes into commercial U.S. pickling cucumber lines. Although carotene content of immature fruit was not quantified here, accumulation of $\beta$-carotene at this stage is controlled by independent genes with additive effects (Navazio and Simon, 2001). This makes it possible to increase $\beta$-carotene content (orange hue) by family selection. EOM 402-10 has possible application for development of high-carotene pickling cucumbers with orange endocarp/mesocarp that will be attractive to consumers based on its nutritional value.

\section{Availability}

Seed of EOM 402-10 may be obtained by addressing requests to P.W. Simon, USDA-ARS, Vegetable Crops Research Unit, Madison, WI (philipp.simon@ars.usda.gov).

\section{Literature Cited}

Cuevas, H.E., H. Song, J.E. Staub, and P.W Simon. 2010. Inheritance of beta-caroteneassociated flesh color in cucumber (Cucumis sativus L.) fruit. Euphytica 171:301-311.

Navazio, J.P. and P.W. Simon. 2001. Dialle analysis of high carotenoid content in cucumbers. J. Amer. Soc. Hort. Sci. 126:100-104.

Simon, P.W. and J.P. Navazio. 1997. Early orange mass 400 , early orange mass 402 , and late orange mass 404: High-carotene cucumber germplasm. HortScience 32:144-145. 